\title{
Differential micropollutants bioaccumulation in European hake and their parasites Anisakis sp.
}

\author{
Mille Tiphaine ${ }^{1}$, Soulier Laurent ${ }^{4}$, Caill-Milly Nathalie ${ }^{2}$, Cresson Pierre ${ }^{3}$, Morandeau Gilles ${ }^{2}$, \\ Monperrus Mathilde ${ }^{1, *}$
}

1 Université de Pau et des Pays de l'Adour, E2S UPPA, CNRS, IPREM, Anglet, France

2 Ifremer, Laboratoire Environnement Ressources d'Arcachon, 64600, Anglet, France

3 Ifremer, Centre Manche Mer du Nord, Laboratoire Ressources Halieutiques Manche Mer du Nord, 150 quai Gambetta, 62200, Boulogne sur Mer, France

${ }^{4}$ Institut des Milieux Aquatiques, 1 Rue Donzac, 64100, Bayonne, France

*Corresponding author : Mathilde Monperrus, email address : mathilde.monperrus@univ-pau.fr

\begin{abstract}
:
Organisms are exposed to various stressors including parasites and micropollutants. Their combined effects are hard to predict. This study assessed the trophic relationship, micropollutants bioaccumulation and infection degree in a host-parasite couple. Carbon and nitrogen isotopic ratios were determined in hake Merluccius merluccius muscle and in its parasite Anisakis sp.. Concentrations of both priority (mercury species and polychlorinated biphenyls congeners) and emerging (musks and sunscreens) micropollutants were also measured for the parasite and its host, to detect potential transfer of contaminants between the two species. The results showed partial trophic interaction between the parasite and its host, in accordance with the Anisakis sp. life encysted in hake viscera cavity. PCB transfer between the two species may result from some lipids uptake by the parasite, while no relation occurred for the two other contaminants. Finally, a positive correlation was found between the number of Anisakis $\mathrm{sp}$. larvae and the methylmercury contamination for hake, emphasizing the assumption that the contamination level in methylmercury can weaken immune system of the host enough to affect parasite infection degree.
\end{abstract}




\section{Graphical abstract}

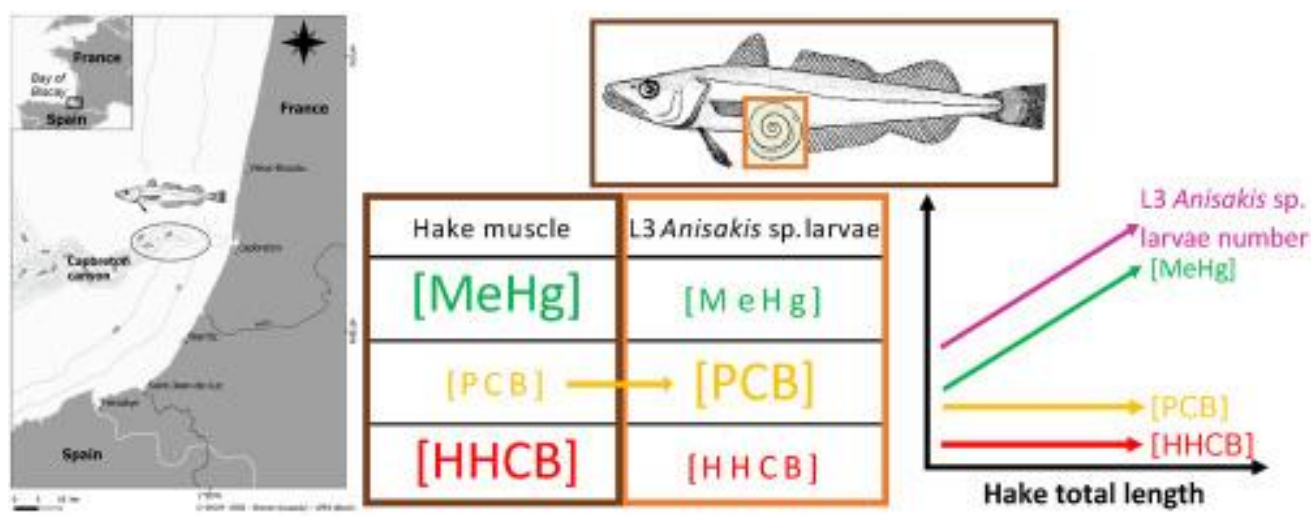

\section{Highlights}

Partial trophic interaction between L3 Anisakis sp. larvae and its host, hake. PCB transfer may result from the uptake of lipids from hake by the parasites. Highly $\mathrm{MeHg}$ level in hake can weaken immune system and increase Anisakis sp. number.

Keywords : Parasite-host system, Mercury, PCB, Emerging contaminants, Nematode 


\section{Introduction}

36 The role of parasites in marine food webs is now recognized as important but largely overlooked

37 (Hudson et al., 2006). As they may have adverse effect on human health, too many parasites might seem as organisms with no ecosystemic role that simply should be eradicated. However, they do not necessarily have adverse effect on hosts nor cause economic or sanitary issues; they are important and integral components of all ecosystems. Healthy ecosystems have healthy parasite communities and assemblages (Marcogliese, 2005). They may be potentially used as indicators of species and ecosystem diversity (Balbuena et al., 1995; Sures et al., 2017) because they reflect the presence of organisms that contribute to their life cycles. They are also indicators of trophic relationships between their successive hosts (Pascual et al., 1996). By strengthening predator/prey links, they could be the glue that holds food webs together. In addition, since highly connected systems are considered more resilient to environmental perturbations (Rooney and McCann, 2012; Sanders et al.,

47 2018; Thompson et al., 2012) and as parasitism results from biotic interactions, high level of parasitism may track ecosystems with higher resistance to environmental perturbations. Due to the contribution of parasites to population dynamics, Lafferty et al., (2008) promote that they could be integrated into food webs models. Accumulating different heavy metals in aquatic systems, they

51 could be used as bioindicators of pollution (Morsy et al., 2012; Sures, 2001). However, the

52 association between parasitism (infection degree), pollution and host health is a complex subject.

53 Cumulated effects of co-occurring parasites and pollutants can be either antagonists (contaminant

54 affects parasites and limits infestation) or synergistics (contaminant affects hosts immune system 55 and enhance infestation), precluding from easy understanding and prediction (Morrill et al., 2014). 
eels. Infection by the swim-bladder nematode Anguillicola crassus increased cortisol concentrations while simultaneously occurring metal and/or PCB contamination reduced plasma cortisol levels.

In the recent years, combining several trophic tracers was demonstrated efficient to understand trophic transfers of organic matter. Carbon and nitrogen stable isotopes have been largely used in trophic ecology, as predators' isotopic ratios are directly linked with isotopic ratios of their diet. Carbon isotopic ratio do not vary much at each trophic level (theoretically $+1 \%$ ), allowing the use of this element as a tracer of organic matter source. On the contrary, nitrogen is gradually enriched (theoretically $+3.4 \%$ ), leading to high $\delta^{15} \mathrm{~N}$ values at high trophic levels (Layman et al., 2012). Nevertheless, stable isotopes are not suited when trophic sources are not isotopically distinct. In these cases, contaminants can also be used in combination (Pethybridge et al., 2018). By example, Hg level was powerful to elucidate trophic pathways in the deep Mediterranean. As fish species considered belonged to the same trophic pathway based on pelagic production, they exhibited comparable isotopic ratios, but had different $\mathrm{Hg}$ levels, as they feed whether in the water column or on the bottom, ie above or below the zone of $\mathrm{Hg}$ production (Cresson et al., 2014). Similarly, in the Bay of Biscay, spatial variation of $\mathrm{Hg}$ contamination was used as a tracer of stock segregation for hake, with higher $\mathrm{Hg}$ burdens in the southern individuals being interpreted as the occurrence of two stocks in the Bay of Biscay (Chouvelon et al., 2014). Combined measurement of PCB and Hg in fish, notably hake, is classical (e.g. Cresson et al., 2015; Dierking et al., 2009; Harmelin-Vivien et al., 2012), as these compounds may affect different systems of the organisms (reproductive or neurologic respectively) and results from different anthropic activities. As they have different chemical properties, they are also powerful tracers of different exchanges of organic matter in food web. Finally, investigating PCB content in different tissues allowed identifying intra-individual fluxes of matter. Lipid transfers between muscle and eggs during oogenesis explained lower PCB burden in females than in males (Bodiguel et al., 2009). Since isotopic relationship between host and parasites is not as straight forward as between predator and prey (Thieltges et al., 2019), coupling several 
trophic tracers can be powerful to gain better understanding of the organic matter exchange between hake and Anisakis sp.

The nematode genus Anisakis is a cosmopolitan endoparasite. Anisakis simplex (s.s.) is the most common species found in hake in NE Atlantic waters (Mattiucci et al., 2004). Its life cycle is heteroxenous with crustaceans -mostly Euphausiids (Smith and Wootten, 1978), but also amphipods or decapod larvae (Baird et al., 2014), being the first intermediate hosts. By the crustacean's consumption, Anisakis sp. at their second larval stage (L2) are transformed into L3 in 3 to 8 days in the hemocoele. The crustaceans are then ingested mainly by teleosts and cephalopods. Anisakis sp. larvae L3 become encysted, enter hypobiosis, and do not undergo transformation. Fish and cephalopods are thus considered as paratenic hosts. Cycle is completed in cetaceans' stomach, after the consumption of teleosts and cephalopods, where L3 larvae are transformed in L4 larvae and then mature adults. After sexual reproduction, eggs are expelled in the digestive tract of cetaceans and evacuated with the faeces. Eggs develop freely in the water. Hatching occur in 20 to 27 days at $5-7$ ${ }^{\circ} \mathrm{C}$. The first larval stage (L1) develops inside the egg then after a second moult (L2), the larvae swims freely in the water to join a crustacean (Baird et al., 2014; Buchmann and Mehrdana, 2016). The life cycle of Anisakis is fairly well known, due to the importance of Anisakis sp. larvae L3 in food hygiene and public health. As Anisakis sp. cannot complete its cycle in humans, ingestion of raw, brined, marinated or undercooked fish fillet or cephalopods can lead to human health issues. Between 2010 and 2014, 80 human anisakidosis (human allergy caused by Anisakis sp. infestation) have been detected by French parasitology laboratories and hospitals, with 4 to 14 cases each year (ANSES, 2017; Dupouy-Camet et al., 2016). In addition, a recent study observed an increased importance of Anisakis during the last decades with potential effects on fish and human health, and on fisheries (Fiorenza et al., 2020).

Hake is an important demersal fishery resource. In the Bay of Biscay, this species is the first landed with 42536 tons caught in 2017 (Ifremer Fisheries Information system, 2018). Its diet varies with ontogeny: juveniles mostly consume pelagic crustaceans, and adults are piscivores, with blue 
whiting, horse mackerel, sardine and also young hake being important preys (Mahe et al., 2007; Rault et al., 2017; Velasco and Olaso, 2000). Due to its diet, hake is one of fish species being an intermediate host for the L3 Anisakis sp. larvae (Aibinu et al., 2019). In addition, its trophic position drives biomagnification and high burdens in Hg (Chouvelon et al., 2014; Cossa et al., 2012) or PCB (Bodiguel et al., 2009). Understanding the contamination and parasitism levels and their combined effects on hake is thus of prime importance for ecological, economical and sanitary reasons.

As the actual magnitude of impact on the host, and a potential direct energy transfer between Anisakis sp. and hake is unknown, this paper is aimed at investigating the relationship between Anisakis sp. L3-larvae and hake. Combined use of stable isotopes and contaminants was employed to investigate the potential transfer of organic matter and of contaminant (mercury, PCB and emergent micropollutants) between host and parasite, and also the relationship between parasite infestation and contamination levels.

\section{Material and methods}

\section{Sampling and samples preparation}

A total of 114 hake individuals (Merluccius merluccius) were collected in 2017 to 2018 by fishermen operating in the south of the Bay of Biscay, on the continental shelf from the Capbreton canyon,at depth ranging between 150 and $200 \mathrm{~m}$ (Figure 1). Sampling occurred in February to June, ie before and during the main reproduction period of hake. Individuals were stored on ice until dissection. In the laboratory, each individual was identified, measured to the nearest $\mathrm{mm}$ (total length), weighted to the nearest g. Sex was identified from a macroscopic examination of the gonads. On each hake, muscle was collected for both stable isotope and contaminant analyses. A sample of white dorsal muscle without skin and bones was taken on all individuals. A small part was used for isotopic analysis and all remaining sample was used for contaminant analyses.

Anisakis sp. L3-larvae (referred as to Anisakis sp. hereafter) were systematically collected at the opening of the visceral cavity of all hake individual, before their leaking to the organs. Parasites were 


\section{Journal Pre-proof}

rinsed with distilled water, frozen at $-20^{\circ} \mathrm{C}$ for $48 \mathrm{~h}$ then decapsulated, counted and pooled to one sample. The amount of matter needed to perform contaminant analyses was high ( $>2 \mathrm{~g}$ dry weight), i.e. a weight corresponding to 200 Anisakis sp. individuals. Analyses were thus performed in pools of parasites collected in 20 hakes randomly selected among hakes with parasite's abundance higher than 200 individuals. All samples (Anisakis sp. pools and hake muscles) were stored frozen, freezedried and grinded.

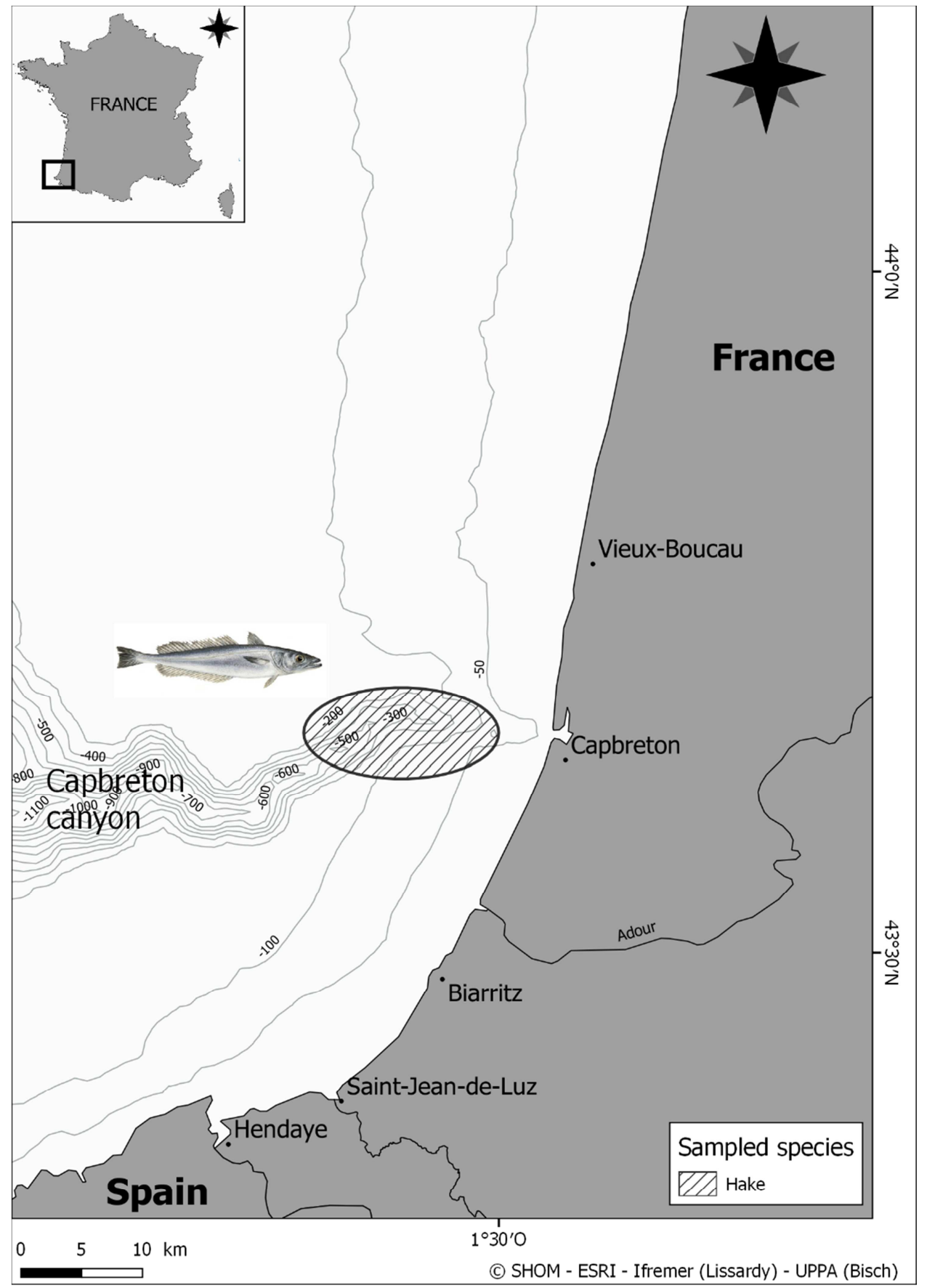

Figure 1: Map of hake sampling area. 
142 Isotopic analyses were performed on a small subsample of grinded hake muscle or of Anisakis pools 143 with a Thermo Scientific Delta V Advantage mass spectrometer coupled to a Thermo Scientific Flash EA1112 elemental analyzer. Results are presented in the classical $\delta$ notation, $\delta X=\left(\frac{R_{\text {sample }}}{R_{\text {standard }}}-1\right) \times$ $14510^{3}$ where $\mathrm{X}$ is ${ }^{13} \mathrm{C}$ or ${ }^{15} \mathrm{~N}$ and $\mathrm{R}$ the ratio between heavy and light isotopes. Standard is Vienna-Pee Dee Belemnite for $\delta^{13} \mathrm{C}$ and atmospheric nitrogen for $\delta^{15} \mathrm{~N}$. Based on replicate measurements of internal laboratory standards, the experimental precisions were $0.13 \%$ and $0.12 \%$ for $\delta^{13} \mathrm{C}$ and $\delta^{15} \mathrm{~N}$. Carbon and nitrogen concentration were measured with the elemental analyzer and used to calculate $\mathrm{C} / \mathrm{N}$ ratios, classical proxy of lipid content in isotopic analyses. High $\mathrm{C} / \mathrm{N}$ ratios are usually interpreted as high lipid content that bias isotopic measurement. All hake $\mathrm{C} / \mathrm{N}$ ratios were lower than 3.5, classically considered as the threshold values requiring lipid correction (Sweeting et al., 2006). Previously published isotopic values were also retrieved in the literature for other fish and invertebrate species living in the Bay of Biscay (Chouvelon et al., 2012).

Methylmercury ( $\mathrm{MeHg}$ ) and inorganic mercury $(\mathrm{IHg})$ were measured by capillary gas chromatography (Focus GC, Thermo Electron) connected to an inductively coupled plasma mass spectrometer (ICPMS X2 series, Thermo Electron). Due to its neurotoxicity, its ability to biomagnify along trophic network (Bryan et al., 1979), and as it the predominant Hg form in fish (Bloom, 1992; Chouvelon et al., 2018). MeHg has been used for the following analyses to represent mercury species. Methodology and analytical set-up for the GC-ICP-MS for Hg speciation analysis are detailed in Monperrus et al.(2005). (Tetramethylammonium hydroxide) under a microwave field and then centrifuged to remove solid particles. The supernatant, stored at $4{ }^{\circ} \mathrm{C}$, was then submitted to derivatization using sodium tetraethylborate (3\%). Quantification of $\mathrm{Hg}$ species was performed by species specific isotope dilution, by adding the appropriate amount of isotopically enriched $\mathrm{Hg}$ standards $\left({ }^{199} \mathrm{Hg}\right.$ and 
${ }^{201} \mathrm{MeHg}$, and by applying isotope pattern deconvolution for data processing (Rodríguez Martín-

Doimeadios et al., 2004). Total mercury ( $\mathrm{Hg})$ concentrations is equal to the sum of $\mathrm{IHg}$ and $\mathrm{MeHg}$

concentrations. Results quality was checked by repeated analyses of blanks and of reference material

IAEA 407 (fish homogenate). Limits of quantification were set to 1.4 and $1.2 \mathrm{ng} \mathrm{g}^{-1} \mathrm{dw}$ for THg and

170

171

172

173 MeHg, respectively.

\section{Musk fragrances, UV-filters, and PCBs analyses}

Personal care products such as musks and UV-filters are used in household products or cosmetic as fragrance ingredients and in suncreens to protect the skin against the harmful effects of ultraviolet radiation, respectively. Because they are only partially eliminated by wastewater treatment plants, they enter aquatic systems leading to organisms exposure (Ternes et al., 2004). Moreover, due to their lipophilic nature and their great stability, these compounds can easily bioaccumulate and biomagnify in the marine trophic food web (Cunha et al., 2018; Reiner and Kannan, 2011; Zhang et al., 2013). On the contrary, PCB are historical contaminants in marine systems. Their toxicity drove their ban in the 1990 's, but due to their persistence, they are still present with high concentrations in marine systems.

Therefore, concentrations of 9 musk fragrances (ADBI, AHMI, AHTN, ATII, HHCB, MA, MK, MM, MX), 5 UV-filters (3-BC, EHMC, 4-MBC, OC, OD-PABA) and 12 PCB congeners ( $C B$ 18, 28, 31, 44, 52, $101,118,138,149,153,180,194)$ were determined in hake muscle and in Anisakis sp. pools by Gas Chromatography-Mass Spectrometry (GC-MS). A Quick, Easy, Cheap, Effective, Rugged and Safe (QuEChERS) method, combining an extraction and a clean-up step before the GC-MS analysis, has been used. Methodology and analytical set-up are detailed in Miossec et al. (2018). Briefly, micropollutants were extracted from an aliquot of $2 \mathrm{~g}$ of homogenized dry tissue (hake or Anisakis $\mathrm{sp}$ pool) by a QuEChERS method. Then, $20 \mu \mathrm{L}$ of the supernatant was injected and submitted to derivatization using helium as carrier gas in a HP-5MS UI capillary column ( $30 \mathrm{~m}$ length $\times 0.25 \mathrm{~mm}$ diameter and $0.25 \mu \mathrm{m}$ film thickness). Results were in good agreement with a sample spiked at 50 $\mathrm{ng} \mathrm{g}^{-1}$ realized with all for target compounds and for each studied species (Supplementary material). 
All concentrations were expressed relatively to dry weight. Concentrations measured for the 12 PCB congeners were summed and expressed with the usual $\Sigma$ PCB notation hereafter.

In order to investigate the potential contaminant transfer between the parasite and its host, the relationship between contaminant concentration in hake and Anisakis sp. have been performed by linear regressions.

Hake contamination level was related to its infection degree by Anisakis sp. in two steps. First, the relationship between the number of Anisakis sp. found in hake and its total length and sex have been investigate by an ANCOVA with total length as covariate and sex as factor, using data from all hake individuals. Second, since the fish contamination can also increase with fish size, the infection degree illustrated by the number of Anisakis sp. was fitted using a linear effect model as depending on total length and micropolluant concentration of hake as continuous variable. This analysis was performed on the subset of hakes the parasites of which were used for contaminant analyses. The model was reduced by a bidirectional elimination procedure based on the Akaike Information Criterion (Borcard et al., 2011). In order to determine active factors, significance of effects in the reduced model was tested by $F$ tests between nested models respecting marginality of the effects (type 2 tests; Fox and Weisberg, 2011). The assumption of normality and homogeneity of variance were checked on 
Results

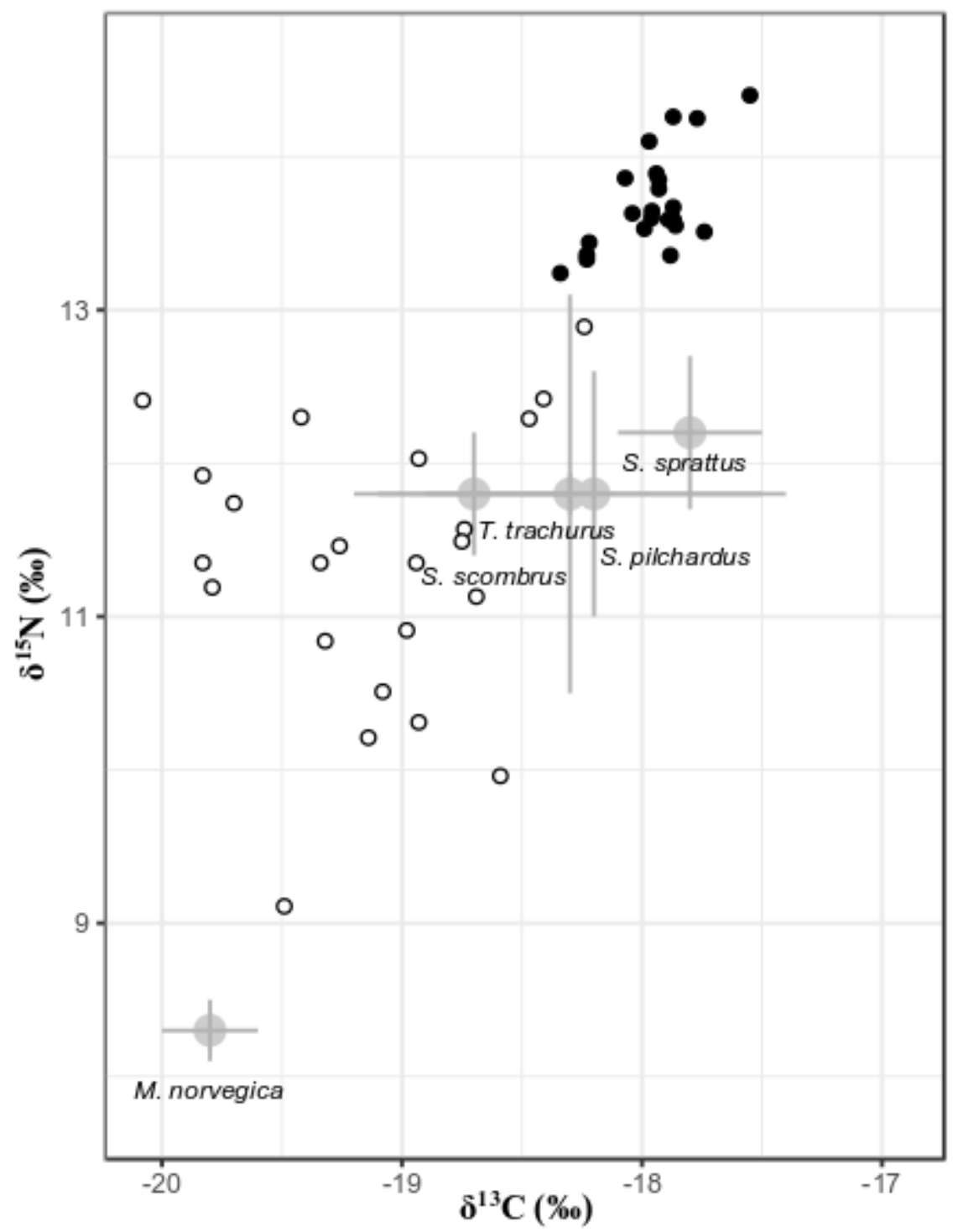

Figure 2: $\delta^{13} \mathrm{C}$ and $\delta^{15} \mathrm{~N}$ signatures for hake $(\bullet)$ and Anisakis sp. ( $\odot$ ) from the Capbreton canyon . In order to complete the food web, pelagic fishes and Euphausiids are displayed in grey and are based on literature values (Chouvelon et al., 2012).

Average isotopic ratios for hake were of $-17.96 \pm 0.18 \%$ and $13.70 \pm 0.31 \%$ for carbon and nitrogen, respectively, and of $-19.13 \pm 0.51 \%$ ond $11.34 \pm 0.90 \%$ o for Anisakis sp., but with a large range of values for both $\delta^{13} \mathrm{C}(-20.8--18.2)$ and $\delta^{15} \mathrm{~N}(9.1-12.9)$ (Figure 2). In addition, $\mathrm{C} / \mathrm{N}$ ratios were higher for Anisakis sp. (5.4 \pm 0.5$)$ than hake (3.1 \pm 0.1$)$ (Table 1). 
Table 1: Stable isotopic signatures in carbon and nitrogen measured in hake muscles and Anisakis sp. pools (mean, standard deviation and range).

\begin{tabular}{|l|c|c|}
\hline & Merluccius merluccius & Anisakis sp. \\
\hline \multirow{2}{*}{ Total length (mm) } & $\begin{array}{c}553 \pm 45 \\
(425-640)\end{array}$ & - \\
\hline \multirow{2}{*}{$\boldsymbol{\delta}^{\mathbf{1 3}} \mathbf{C}(\%)$} & $-17.9 \pm 0.2$ & $-19.1 \pm 0.5$ \\
& $(-18.3--17.6)$ & $(-20.8--18.2)$ \\
\hline \multirow{2}{*}{$\boldsymbol{\delta}^{\mathbf{1 5}} \mathbf{N}(\%)$} & $13.7 \pm 0.3$ & $11.4 \pm 0.9$ \\
& $(13.2-14.4)$ & $(9.1-12.9)$ \\
\hline \multirow{2}{*}{$\mathbf{C} \mathbf{N}$} & $3.1 \pm 0.1$ & $5.4 \pm 0.5$ \\
& $(3.1-3.2)$ & $(4.6-6.1)$ \\
\hline
\end{tabular}

Micropollutants level according to species

THg and MeHg concentrations were on average 6.4 and 4.8 times higher in hake than in Anisakis sp. pools, respectively (Table 2). No significant relationship between mercury concentration in hake and Anisakis sp. could be observed (Figure 3A). Among the 12 investigated PCB, congeners 101,118, 138, 149, 153, and 180 were measured in all hake and parasite samples tested whereas PCB 194 was quantified in Anisakis sp. only. Unlike Hg, PCB concentrations were 3 times higher in Anisakis sp. than in hake (Figure 3B). Three emergent compounds, i.e. one musk (ATNH) and two UV-filters (EHMC and OC) have been detected but in few individuals. Contrarily HHCB have been detected in almost all hake and Anisakis sp. samples tested and consequently been used to look at size and parasite effects. No relationship between HHCB concentration in host and parasite could be detected (Figure 3C).

Table 2: Micropollutants concentrations measured in hake muscles and Anisakis sp. pools (mean, standard deviation and occurrence).

\begin{tabular}{|l|c|c|}
\hline & Merluccius merluccius & Anisakis sp. \\
\hline Mercury species $\left(\mathbf{n g ~ g}^{-1} \mathbf{d w}\right)$ & & $239 \pm 196(20 / 20)$ \\
\hline THg & $1543 \pm 795(20 / 20)$ & $206 \pm 176(20 / 20)$ \\
\hline MeHg & $1000 \pm 450(20 / 20)$ & $11 \pm 5(19 / 20)$ \\
\hline PCB congeners (ng g $\left.{ }^{-1} \mathbf{d w}\right)$ & & $17 \pm 10(20 / 20)$ \\
\hline PCB 101 & $2 \pm 1(20 / 20)$ & \\
\hline PCB 149 & $5 \pm 2(20 / 20)$ & \\
\hline
\end{tabular}


Journal Pre-proof

\begin{tabular}{|c|c|c|}
\hline PCB 118 & $1 \pm 1(17 / 20)$ & $8 \pm 4(20 / 20)$ \\
\hline PCB 153 & $21 \pm 9(20 / 20)$ & $51 \pm 36(20 / 20)$ \\
\hline PCB 138 & $17 \pm 8(20 / 20)$ & $46 \pm 27(20 / 20)$ \\
\hline PCB 180 & $13 \pm 7(20 / 20)$ & $32 \pm 18(20 / 20)$ \\
\hline PCB 194 & $1 \pm 1(10 / 20)$ & $<\operatorname{LOQ}(0 / 20)$ \\
\hline$\sum \mathbf{P C B}$ & $61 \pm 28(20 / 20)$ & $165 \pm 99(20 / 20)$ \\
\hline \multicolumn{3}{|c|}{ Musk fragrances $\left(\mathrm{ng} \mathrm{g}^{-1} \mathrm{dw}\right)$} \\
\hline ATNH & $1 \pm 1(4 / 20)$ & $1 \pm 2(9 / 20)$ \\
\hline НHCB & $1 \pm 1(20 / 20)$ & $3 \pm 3(14 / 20)$ \\
\hline \multicolumn{3}{|c|}{ UV-filters (ng g ${ }^{-1}$ dw) } \\
\hline OC & $<\operatorname{LOQ}(0 / 20)$ & $15 \pm 22(12 / 20)$ \\
\hline EHMC & $1 \pm 1(5 / 20)$ & $<\operatorname{LOQ}(0 / 20)$ \\
\hline
\end{tabular}



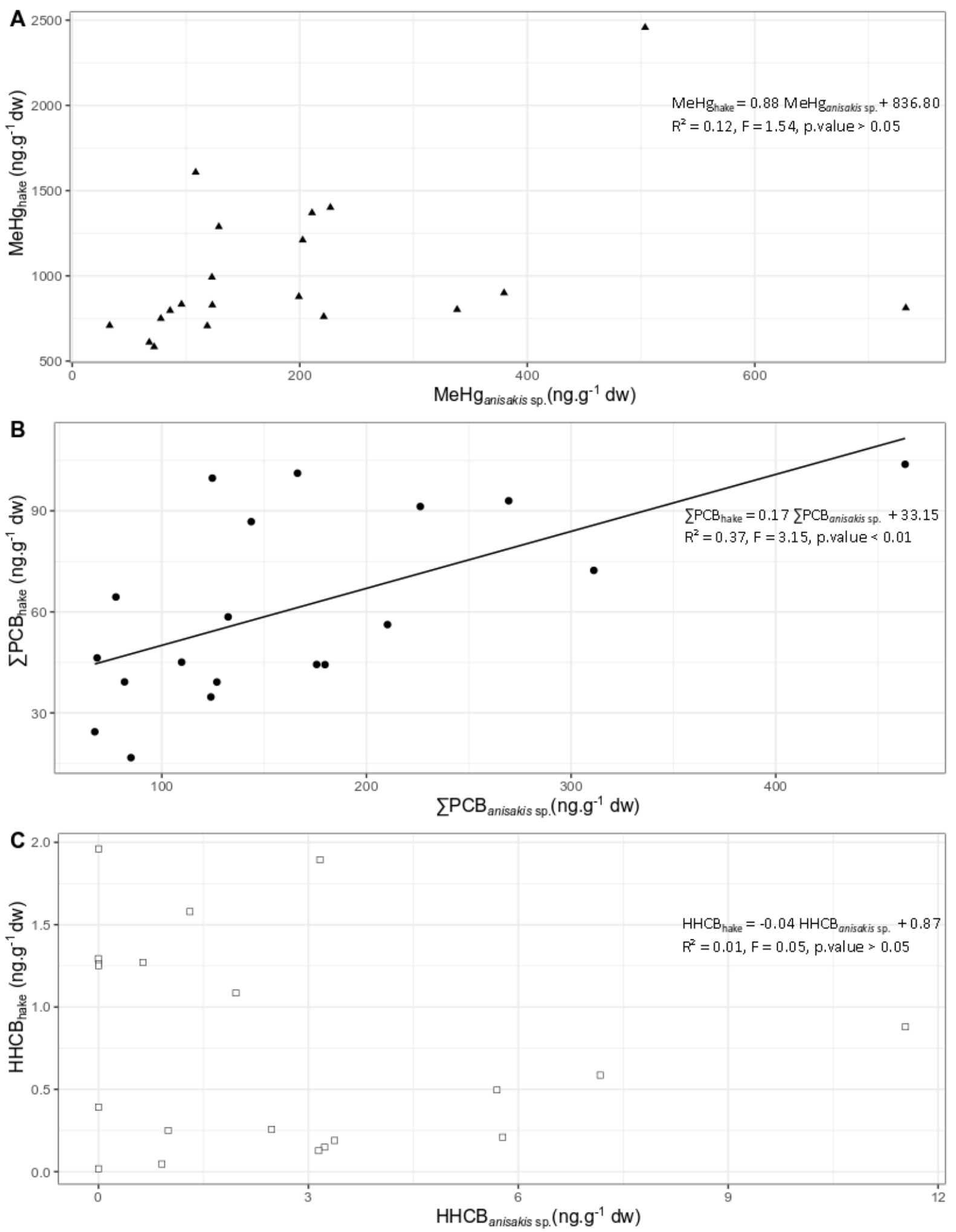

Figure 3: Relationship between hake contamination and its Anisakis sp. pool contamination in MeHg (A), 


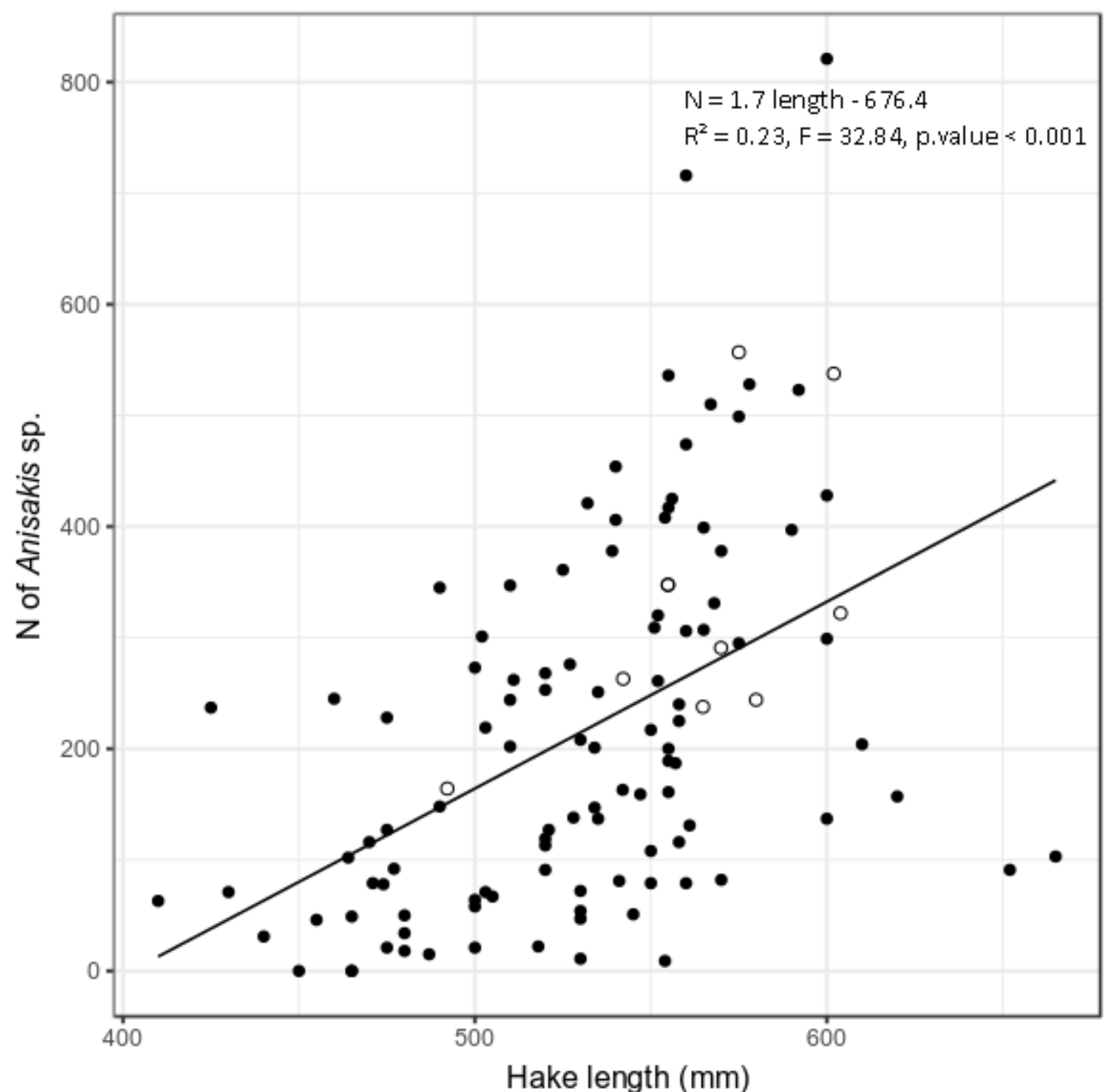

Figure 4: Relationship between the number $(\mathrm{N})$ of Anisakis sp. (proxy of hake infection degree) and hake total length and sex $(\bullet$ female, $\circ$ male) .

A significant increase of the infection by Anisakis sp. with the total length of its host was found $(F=28.8$, p.value $<0.05)$ (Figure 4). However, no difference according to fish sex on the infection degree has been observed $(F=1.4$, p.value $>0.05)$, despite males had a higher number of parasite than females, (327 \pm 134 and $209 \pm 164$ for males and females respectively). In addition, larger hakes were significantly more contaminated in $\mathrm{MeHg}(\mathrm{F}=6.8$, p.value $<0.05)$ but not in $\mathrm{PCB}(\mathrm{F}=0.9$, p.value $>0.05)$ and in $\mathrm{HHCB}\left(\mathrm{F}=6.0 .10^{-4}\right.$, p.value $\left.>0.05\right)$ (Figure $\left.5 \mathrm{~A}\right)$. The higher the $\mathrm{MeHg}$ 
concentration in hake muscle, the higher the number of Anisakis sp. $(\mathrm{F}=10.5$, p.value $<0.01)$ (Figure

5B). Similar relationships were not observed for other micropollutants tested ( $\Sigma P C B$ and HHCB).
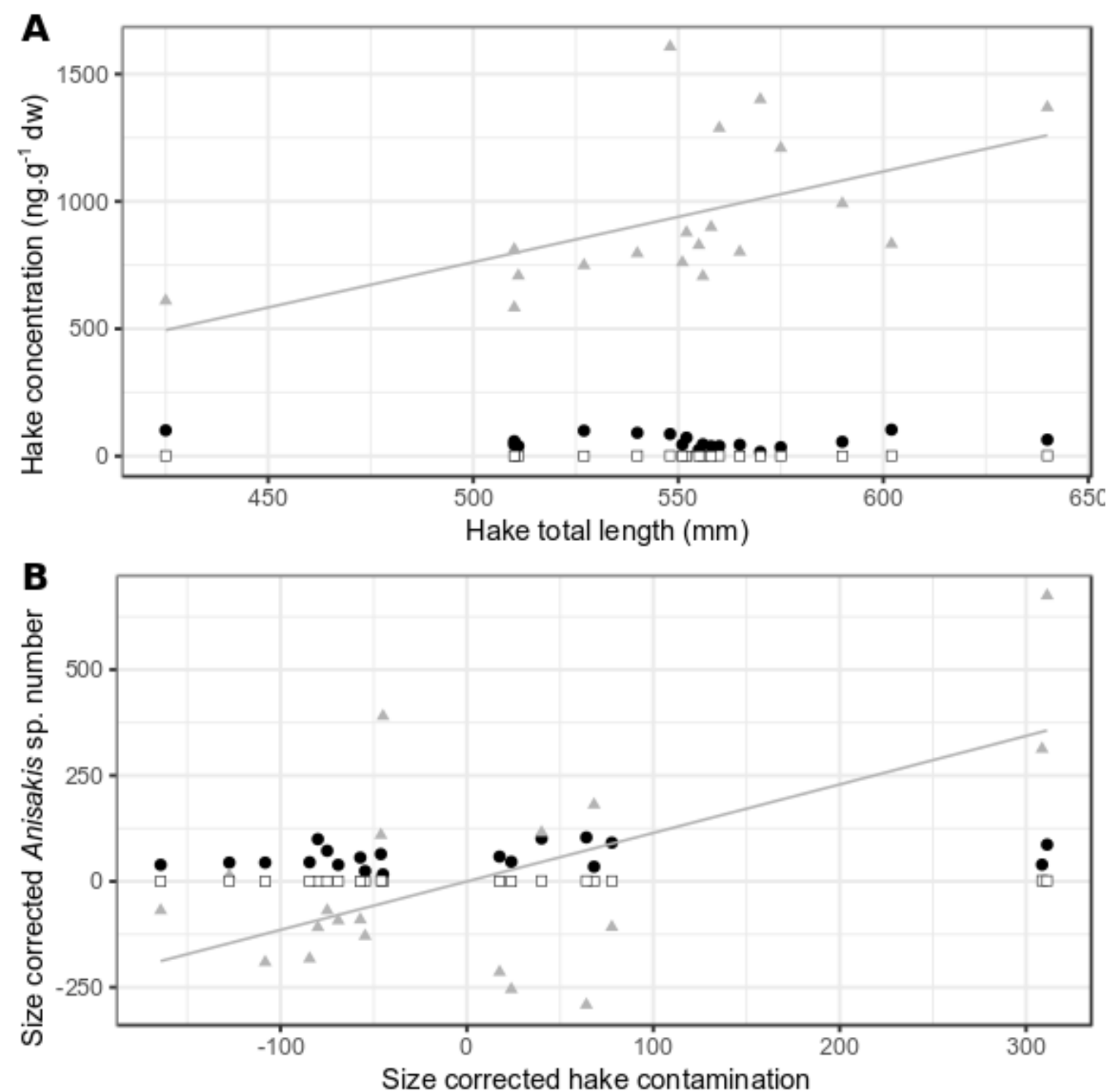

Figure 5: Relationship between hake contamination level ( $\left.\triangle \mathrm{MeHg}, \bullet \sum \mathrm{PCB}, \square \mathrm{HHCB}\right)$ and its total length (A). Relationship between hake infection degree and its contamination level $\left(\triangle \mathrm{MeHg}, \bullet \sum \mathrm{PCB}\right.$, $\square$ HHCB) corrected by hake total length (B).

\section{Discussion}

Trophic relationship between hake and Anisakis sp.

Stable isotopes are widely used to identify trophic interactions and to determine trophic positions of organisms in the food webs but for classical "prey-predator" or "primary producer - grazers" interactions. Direct applications of isotopic relationships calibrated for these interactions (i.e. fractionation factors of $\sim 1 \%$ for carbon and of $\sim 3 \%$ for nitrogen) to host-parasite relationship are 
called into question (Thieltges et al., 2019). The present study revealed that the Anisakis sp. were consistently depleted in $\delta^{15} \mathrm{~N}$ in relation to their host, as observed in Pinnegar et al. (2001) between Merlangius merlangus (Gadiforme) and its parasite Hysterothylacium aduncum (Nematode Ascaridoidea). Nitrogen isotopic ratios measured for Anisakis sp. was very close to literature values for small pelagic fish - themselves known for zooplankton predation behavior. This similarity could be interpreted like a classical of predator-prey relationship between Anisakis sp. and Euphausiids. Isotopic differences between Anisakis sp. and Euphausiids are of $2.36 \pm 0.87 \%$ ond $1.17 \pm 0.53 \%$ o for $\mathrm{N}$ and $\mathrm{C}$, i.e. close to theoretical trophic enrichment factors between predator and preys, while lower values for Anisakis sp. than for hake can track the absence of trophic relationships. Anisakis sp. isotopic ratios would reflect thus a diet mostly based on the consumption of a previous host such as Euphausiids, first known intermediate host (Smith and Wootten, 1978). This hypothesis would be consistent with the fact that Anisakis sp. is encysted when in hakes' viscera cavity, potentially limiting matter exchanges. Nevertheless, large variability in Anisakis sp. isotopic ratios may demonstrate some variability in trophic behavior. In addition, isotopic relationship between host and parasites was questioned and may appear not straightforward as the relationship established between preys and predators (Pinnegar et al., 2001; Thieltges et al., 2019). The ability of parasites to use selectively some macromolecules from its host may explain odd factors. Parasites may be example selectively use ${ }^{14} \mathrm{~N}$-enriched ammonia excreted from host tissues for amino acid synthesis (Barrett, 1981). Similarly, as lipids have lower $\delta^{13} \mathrm{C}$ values than proteins, their selective use may blur isotopic relationship, notably as isotopic ratios are measured for host muscle, a lipid poor tissue. Comparing tissue-specific and parasites isotopic ratios may be a pertinent research pathway to better address relationship established (Pinnegar et al., 2001). The isotopic variability measured in Anisakis sp. may also reflect that the nature of compounds uptaken may vary along with nutritional needs of the parasite. Future investigation of the actual pathway and macromolecules used by parasites, as well as the calibration of accurate isotopic fractionation factors are needed before being able to use stable isotope as tracers of host-parasites relationships. 
As diet constitutes the main contamination pathway for $\mathrm{Hg}$ and $\mathrm{PCB}$, contaminant concentration in preys is an essential parameter in understanding bioaccumulation pattern in predators (Cresson et al., 2014; Harmelin-Vivien et al., 2012; Kenji et al., 2020). Since stable isotopes failed to ascertain the relationship between hake and Anisakis sp., contaminant could be powerful tools to look differently at this relationship. The absence of relationship between hake and Anisakis sp. for MeHg and HHCB concentrations can be viewed as consistent with the absence of link between these species. This hypothesis could nevertheless be formally confirmed in the absence of measurement in Euphausiids. Previous studies documented MeHg behavior in fish, notably driven by the link between $\mathrm{Hg}$ and some aminoacids (Harmelin-Vivien et al., 2012; Webb et al., 2006). The absence of relationship between $\mathrm{Hg}$ concentration in hake and parasites may track the absence of major protein exchanges between the two species. This assumption was confirmed by literature: nematodes such as Anisakis that used fish as paratenic host with an encapsulated visceral life had lowest ability to concentrate metals (Dural et al., 2011; Nachev and Sures, 2016)., notably when compared with other major parasitic groups, such as tapeworms and acanthocephalans that live within the host's intestine (Sures et al., 1999, 1997). Regarding other micropollutant tested, the pattern was somehow blurred. As these compounds are emergent, they have received less scientific interest so far. Since their behavior is less documented, mechanisms explaining the absence of a clear relationship between concentrations in hake and Anisakis sp. are hard to identify. In hake, muscle may not be the most suited organ to measure these compounds, and future studies could include measurement in other organs with involved in detoxication metabolism, such as liver, spleen or gallbladder.

Fat content is usually low in most endoparasites. As they cannot produce their own long chain fatty acids, they rely on their host to take up lipids (Maule and Marks, 2006). As PCBs are lipophilic, they 317 are usually transferred along with lipids. By example, oogenesis in hake is associated with PCB 318 transfer, explaining sexual difference in PCB concentration in hake (Bodiguel et al., 2009). Therefore, 
the PCB concentration are usually lower in parasite than its host illustrating a low transfer between the two species In this study, the PCB content was nearly 3 time higher in Anisakis sp than in hake.

Even if the exchanges of organic contaminants between host and parasites have been less investigated than the exchanges of metals most studies usually consider that parasites do not accumulate organic contaminants (Yen Le et al. 2014). However, the significant relationship between PCB concentrations in Anisakis sp. and hake could track some exchanges. Once ingested by its host, the parasite crosses the stomach wall and encysts in the abdominal cavity. Cuticle synthesis requires high fatty acids content, notably sterols, that Anisakis sp. presumably take up from its host (Mika et al., 2010). This lipid uptake can explain increase of PCB concentration between hake and Anisakis sp. Such a transfer would also be consistent with the high $\mathrm{C} / \mathrm{N}$ ratio observed here, consistently with previous studies that demonstrated different lipid levels all along parasite life cycle (Abollo and Pascual, 2001). Nevertheless, this result is contradictory with the accepted hypothesis of an arrested development in paratenic host, and by the fact that Anisakis L3 larvae do not use hake resources, usually exemplified by lower PCB concentrations in parasites than in host (Sures, 2004; Yen Le et al. 2014). The results obtained here combing several trophic tracers may demonstrate that limited exchanges occur: blurred isotopic and Hg patterns may be consistent with no proteins exchange between hake and Anisakis; results based on PCB on the contrary may contrarily testify some exchanges of lipids and lipid-associated contaminants, even if of minor intensity. Assuming a PCB biomagnification factor of $\sim 5$ (i.e. a 5-time increase of PCB concentrations at each trophic level, (e.g. Fisk et al., 2001) and keeping in mind that Anisakis tissues are lipid-rich (highlighted by high $\mathrm{C} / \mathrm{N}$ ratios), the high $\mathrm{PCB}$ concentration in Anisakis cannot be explained only by the consumption of Euphausiids. Even if exchanges of lipid occur between Euphausiids and Anisakis, considering other exchanges is needed to explain higher PCB concentration in Anisakis than in hake. If exchanges only occurred between Anisakis and Euphausiids, the parasite could be considered to be at a trophic level

343 similar to that of zooplankton-feeding fish, i.e. one trophic level below hake. Thus, PCB 344 concentrations should be somehow lower. Nevertheless, the low sample size of the present study 
and the impossibility to include Euphausiids and zooplankton-feeding fish in this study precluded from reaching a formal conclusion. Further measurements of isotopic ratios, lipids and contaminants concentrations is needed to accurately depict the complex exchanges of matter between host and parasites.

\section{Relationship between fish contamination and degree of infection}

Previous studies demonstrated that combined effects of contaminants and parasites on host are hard to identify and predict. In the present study, parasites number and $\mathrm{Hg}$ contamination were both correlated with hake length. Size effect of $\mathrm{Hg}$ increase is classical in hake and explained by bioaccumulation and chronic exposure to contaminant (Cossa et al., 2012; Cresson et al., 2015; Harmelin-Vivien et al., 2012). The same mechanism were proposed to explain higher parasite number in large individuals (Morsy et al., 2012). In addition, the parasite number in hake was generally higher in males than in females despite being non-significant. This may be explained by the sexual dimorphism in fish size. A slower growth rate of males (de Pontual et al., 2006) implies a longer expose time to parasite. Moreover, larger fish increase the capacity to have larger number, size and various species of prey generating more interaction in the ecosystem and thus in turn increasing the probability of exposition to infected prey (Hudson et al., 2006; Morsy et al., 2012). Such an effect of sexual dimorphism and differential growth rate was already proposed to explain difference in contamination in hake (Cossa et al., 2012; Harmelin-Vivien et al., 2012).

In the present study, fish contamination (notably in $\mathrm{MeHg}$ ) and degree of parasitism are correlated, even after removing size effect on both parameters. Such a result might be consistent with a synergistic effect of contaminant and parasites. Contaminant may presumably weaken hake's immune system, leading to enhanced parasitic infestation. Previous studies demonstrated that MeHg at concentrations lower than levels measured in the present study (300 to $400 \mathrm{ng} \mathrm{g}^{-1}$ in fish muscle) weaken immune system of marine fish species (Guardiola et al., 2016; Ren et al., 2019). In addition an increase of parasite load in highly contaminated fish was also observed in other studies (Sagerup 
et al., 2009; Sures and Knopf, 2012). Other studies also demonstrated some effect of PCBs on

372 immune system, but at concentrations way higher than concentrations measured here (Sures and

Knopf, 2012).

374

375

376

377

378

379

380

381

382

383

\section{Conclusions}

The present data indicated that average contamination levels in parasite were lower than in its host for $\mathrm{Hg}$ and emergent micropollutants but not for $\mathrm{PCB}$ and that isotopic relationship was not straightforward. These results testified some complex trophic transfers, consistent with functional optimization of the parasite, and its encysted nature in hake. In addition, parasites number increases in highly $\mathrm{Hg}$ contaminated hake individual, presumably as a result of a weakened immune system of the host. Present results call for extended analyses of the complex relationship established between hosts and parasites, notably regarding the nature and the intensity of the organic matter fluxes. They are nevertheless consistent with the current idea of the importance of parasites as important drivers of marine ecosystems.

\section{Acknowledgements}

The research leading to these results has received funding from the ERDF (European Regional Development Fund) and AEAG (Agence de I'Eau Adour-Garonne) under the MICROPOLIT project. Authors are grateful to Maud Ezan, Aurore Gueux and Carole Miossec who helped in samples preparation and contaminant analyses and to Muriel Lissardy who drawn the sampling map.

\section{References}

Abollo, E., Pascual, S., 2001. Element concentration variability in the whaleworm Anisakis simplex s.l. Parasitol. Int. 50, 115-119. https://doi.org/10.1016/S1383-5769(01)00069-1

Aibinu, I.E., Smooker, P.M., Lopata, A.L., 2019. Anisakis Nematodes in Fish and Shellfish- from infection to allergies. Int. J. Parasitol. Parasites Wildl. 9, 384-393. https://doi.org/10.1016/j.ijppaw.2019.04.007

ANSES, 2017. Fiche de description de danger biologique transmissible par les aliments / Anisakis spp., Pseudoterranova spp. https://www.anses.fr/fr/system/files/BIORISK2016SA0071Fi.pdf

Baird, F.J., Gasser, R.B., Jabbar, A., Lopata, A.L., 2014. Foodborne anisakiasis and allergy. Mol. Cell. Probes 28, 167-174. https://doi.org/10.1016/j.mcp.2014.02.003 
Balbuena, J.A., Aznar, F.J., Fernández, M., Raga, J.A., 1995. Parasites as indicators of social structure and stock identity of marine mammals, in: Blix, A.S., Walløe, L., Ulltang, Ø. (Eds.), Developments in Marine Biology, Whales, Seals, Fish and Man. Elsevier Science, pp. 133-139. https://doi.org/10.1016/S0163-6995(06)80017-X

Barrett, J., 1981. Biochemistry of Parasitic Helminths., London: Macmillan. ed.

Bloom, N.S., 1992. On the Chemical Form of Mercury in Edible Fish and Marine Invertebrate Tissue. Can. J. Fish. Aquat. Sci. 49, 1010-1017. https://doi.org/10.1139/f92-113

Bodiguel, X., Loizeau, V., Le Guellec, A.-M., Roupsard, F., Philippon, X., Mellon-Duval, C., 2009. Influence of sex, maturity and reproduction on $P C B$ and $p, p^{\prime} D D E$ concentrations and repartitions in the European hake (Merluccius merluccius, L.) from the Gulf of Lions (N.W. Mediterranean). Sci. Total Environ. 408, 304-311. https://doi.org/10.1016/j.scitotenv.2009.10.004

Borcard, D., Gillet, F., Legendre, P., 2011. Numerical Ecology with R. Springer.

Bryan, G.W., Waldichuk, M., Pentreath, R.J., Darracott, A., 1979. Bioaccumulation of Marine Pollutants. Philos. Trans. R. Soc. Lond. B. Biol. Sci. 286, 483-505.

Buchmann, K., Mehrdana, F., 2016. Effects of anisakid nematodes Anisakis simplex (s.l.), Pseudoterranova decipiens (s.l.) and Contracaecum osculatum (s.I.) on fish and consumer health. Food Waterborne Parasitol., Foodborne Parasites in Cold Climates 4, 13-22. https://doi.org/10.1016/j.fawpar.2016.07.003

Chouvelon, T., Caurant, F., Cherel, Y., Simon-Bouhet, B., Spitz, J., Bustamante, P., 2014. Species- and size-related patterns in stable isotopes and mercury concentrations in fish help refine marine ecosystem indicators and provide evidence for distinct management units for hake in the Northeast Atlantic. ICES J. Mar. Sci. 71, 1073-1087. https://doi.org/10.1093/icesjms/fst199

Chouvelon, T., Cresson, P., Bouchoucha, M., Brach-Papa, C., Bustamante, P., Crochet, S., MarcoMiralles, F., Thomas, B., Knoery, J., 2018. Oligotrophy as a major driver of mercury bioaccumulation in medium-to high-trophic level consumers: A marine ecosystemcomparative study. Environ. Pollut. 233, 844-854. https://doi.org/10.1016/j.envpol.2017.11.015

Chouvelon, T., Spitz, J., Caurant, F., Mèndez-Fernandez, P., Autier, J., Lassus-Débat, A., Chappuis, A., Bustamante, P., 2012. Enhanced bioaccumulation of mercury in deep-sea fauna from the Bay of Biscay (north-east Atlantic) in relation to trophic positions identified by analysis of carbon and nitrogen stable isotopes. Deep Sea Res. Part Oceanogr. Res. Pap. 65, 113-124. https://doi.org/10.1016/j.dsr.2012.02.010

Cossa, D., Harmelin-Vivien, M., Mellon-Duval, C., Loizeau, V., Averty, B., Crochet, S., Chou, L., Cadiou, J.-F., 2012. Influences of Bioavailability, Trophic Position, and Growth on Methylmercury in Hakes (Merluccius merluccius) from Northwestern Mediterranean and Northeastern Atlantic. Environ. Sci. Technol. 46, 4885-4893. https://doi.org/10.1021/es204269w

Cresson, P., Bouchoucha, M., Morat, F., Miralles, F., Chavanon, F., Loizeau, V., Cossa, D., 2015. A multitracer approach to assess the spatial contamination pattern of hake (Merluccius merluccius) in the French Mediterranean. Sci. Total Environ. 532, 184-194. https://doi.org/10.1016/j.scitotenv.2015.06.020

Cresson, P., Fabri, M.C., Bouchoucha, M., Brach Papa, C., Chavanon, F., Jadaud, A., Knoery, J., Miralles, F., Cossa, D., 2014. Mercury in organisms from the Northwestern Mediterranean slope: Importance of food sources. Sci. Total Environ. 497-498, 229-238. https://doi.org/10.1016/j.scitotenv.2014.07.069

Cunha, S.C., Trabalón, L., Jacobs, S., Castro, M., Fernandez-Tejedor, M., Granby, K., Verbeke, W., Kwadijk, C., Ferrari, F., Robbens, J., Sioen, I., Pocurull, E., Marques, A., Fernandes, J.O., Domingo, J.L., 2018. UV-filters and musk fragrances in seafood commercialized in Europe Union: Occurrence, risk and exposure assessment. Environ. Res. 161, 399-408. https://doi.org/10.1016/j.envres.2017.11.015

de Pontual, H., Groison, A.L., Piñeiro, C., Bertignac, M., 2006. Evidence of underestimation of European hake growth in the Bay of Biscay, and its relationship with bias in the agreed 
method of age estimation. ICES https://doi.org/10.1016/j.icesjms.2006.07.007

Dierking, J., Wafo, E., Schembri, T., Lagadec, V., Nicolas, C., Letourneur, Y., Harmelin-Vivien, M., 2009. Spatial patterns in PCBs, pesticides, mercury and cadmium in the common sole in the NW Mediterranean Sea, and a novel use of contaminants as biomarkers. Mar. Pollut. Bull. 58, 1605-1614. https://doi.org/10.1016/j.marpolbul.2009.07.008

Dupouy-Camet, J., Touabet-Azouzi, N., Fréalle, E., Van Cauteren, D., Yera, H., Moneret-Vautrin, A., 2016. Incidence de l'anisakidose en France. Enquête rétrospective 2010-2014. Bull Epidémiol Hebd (5-6), 64-70. http://www.invs.sante.fr/beh/2016/5-6/2016_5-6_1.html

Dural, M., Genc, E., Sangun, M.K., Güner, Ö., 2011. Accumulation of some heavy metals in Hysterothylacium aduncum (Nematoda) and its host sea bream, Sparus aurata (Sparidae) from North-Eastern Mediterranean Sea (Iskenderun Bay). Environ. Monit. Assess. 174, 147155. https://doi.org/10.1007/s10661-010-1445-0

Fiorenza, E.A., Wendt, C.A., Dobkowski, K.A., King, T.L., Pappaionou, M., Rabinowitz, P., Samhouri, J.F., Wood, C.L., 2020. It's a wormy world: Meta-analysis reveals several decades of change in the global abundance of the parasitic nematodes Anisakis spp. and Pseudoterranova spp. in marine fishes and invertebrates. Glob. Change Biol. 26, 2854-2866. https://doi.org/10.1111/gcb.15048

Fisk, A.T., Hobson, K.A., Norstrom, R.J., 2001. Influence of Chemical and Biological Factors on Trophic Transfer of Persistent Organic Pollutants in the Northwater Polynya Marine Food Web. Environ. Sci. Technol. 35, 732-738. https://doi.org/10.1021/es001459w

Fox, J., Weisberg, S., 2011. An $\{R\}$ Companion to Applied Regression.

Guardiola, F.A., Chaves-Pozo, E., Espinosa, C., Romero, D., Meseguer, J., Cuesta, A., Esteban, M.A., 2016. Mercury Accumulation, Structural Damages, and Antioxidant and Immune Status Changes in the Gilthead Seabream (Sparus aurata L.) Exposed to Methylmercury. Arch. Environ. Contam. Toxicol. 70, 734-746. https://doi.org/10.1007/s00244-016-0268-6

Harmelin-Vivien, M., Bodiguel, X., Charmasson, S., Loizeau, V., Mellon-Duval, C., Tronczyński, J., Cossa, D., 2012. Differential biomagnification of PCB, PBDE, Hg and Radiocesium in the food web of the European hake from the NW Mediterranean. Mar. Pollut. Bull. 64, 974-983. https://doi.org/10.1016/j.marpolbul.2012.02.014

Hudson, P.J., Dobson, A.P., Lafferty, K.D., 2006. Is a healthy ecosystem one that is rich in parasites? Trends Ecol. Evol. 21, 381-385. https://doi.org/10.1016/j.tree.2006.04.007

Ifremer Fisheries Information system, 2018. Activité des navires de pêche 2017 : façade Atlantique. https://archimer.ifremer.fr/doc/00490/60174/

Kenji, Y., Keisuke, M., Gen, K., Shigeaki, K., Yasuhisa, H., Akito, M., Megumi, Y., 2020. Food sources are more important than biomagnification on mercury bioaccumulation in marine fishes. Environ. Pollut. 113982. https://doi.org/10.1016/j.envpol.2020.113982

Lafferty, K.D., Allesina, S., Arim, M., Briggs, C.J., De Leo, G., Dobson, A.P., Dunne, J.A., Johnson, P.T.J., Kuris, A.M., Marcogliese, D.J., Martinez, N.D., Memmott, J., Marquet, P.A., McLaughlin, J.P., Mordecai, E.A., Pascual, M., Poulin, R., Thieltges, D.W., 2008. Parasites in food webs: the ultimate missing links. Ecol. Lett. 11, 533-546. https://doi.org/10.1111/j.14610248.2008.01174.x

Layman, C.A., Araujo, M.S., Boucek, R., Hammerschlag-Peyer, C.M., Harrison, E., Jud, Z.R., Matich, P., Rosenblatt, A.E., Vaudo, J.J., Yeager, L.A., Post, D.M., Bearhop, S., 2012. Applying stable isotopes to examine food-web structure: an overview of analytical tools. Biol. Rev. Camb. Philos. Soc. 87, 545-562. https://doi.org/10.1111/j.1469-185X.2011.00208.x

Mahe, K., Amara, R., Bryckaert, T., Kacher, M., Brylinski, J.M., 2007. Ontogenetic and spatial variation in the diet of hake (Merluccius merluccius) in the Bay of Biscay and the Celtic Sea. ICES J. Mar. Sci. 64, 1210-1219. https://doi.org/10.1093/icesjms/fsm100

Marcogliese, D.J., 2005. Parasites of the superorganism: Are they indicators of ecosystem health? Int. J. Parasitol., Annual Scientific Meeting of the Australian Society for Parasitology, Freemantle Esplanade Hotel, 2004 Highlights 35, 705-716. https://doi.org/10.1016/j.ijpara.2005.01.015 
Mattiucci, S., Abaunza, P., Ramadori, L., Nascetti, G., 2004. Genetic identification of Anisakis larvae in European hake from Atlantic and Mediterranean waters for stock recognition. J. Fish Biol. 65, 495-510. https://doi.org/10.1111/j.0022-1112.2004.00465.x

Maule, A.G., Marks, N.J., 2006. Parasitic FlatWorms: Molecular Biology, Biochemistry, Immunology and Physiology. URL https://www.cabi.org/bookshop/book/9780851990279/ (accessed 1.27.20).

Mika, A., Gołebiowski, M., Szafranek, J., Rokicki, J., Stepnowski, P., 2010. Identification of lipids in the cuticle of the parasitic nematode Anisakis simplex and the somatic tissues of the Atlantic cod Gadus morhua. Exp. Parasitol. 124, 334-340. https://doi.org/10.1016/j.exppara.2009.11.013

Miossec, C., Lanceleur, L., Monperrus, M., 2018. Adaptation and validation of QuEChERS method for the simultaneous analysis of priority and emerging pollutants in sediments by gas chromatography-mass spectrometry. Int. J. Environ. Anal. Chem. 98, 695-708. https://doi.org/10.1080/03067319.2018.1496245

Monperrus, M., Tessier, E., Veschambre, S., Amouroux, D., Donard, O., 2005. Simultaneous speciation of mercury and butyltin compounds in natural waters and snow by propylation and species-specific isotope dilution mass spectrometry analysis. Anal. Bioanal. Chem. 381, 854-862. https://doi.org/10.1007/s00216-004-2973-7

Morrill, A., Provencher, J.F., Forbes, M.R., 2014. Testing for dual impacts of contaminants and parasites on hosts: the importance of skew. Environ. Rev. 22, 445-456. https://doi.org/10.1139/er-2014-0026

Morsy, K., Bashtar, A.-R., Abdel-Ghaffar, F., Mehlhorn, H., Quraishy, S.A., El-Mahdi, M., Al-Ghamdi, A., Mostafa, N., 2012. First record of anisakid juveniles (Nematoda) in the European seabass Dicentrarchus labrax (family: Moronidae), and their role as bio-indicators of heavy metal pollution. Parasitol. Res. 110, 1131-1138. https://doi.org/10.1007/s00436-011-2600-4

Nachev, M., Sures, B., 2016. Environmental parasitology: Parasites as accumulation bioindicators in the marine environment. J. Sea Res., Ecology and Evolution of Marine Parasites and Diseases 113, 45-50. https://doi.org/10.1016/j.seares.2015.06.005

Pascual, S., González, Á.F., Arias, C., Guerra, Á., 1996. Biotic relationships of Illex coindetii and Todaropsis eblanae (Cephalopoda, Ommastrephidae) in the Northeast Atlantic: Evidence from parasites. https://doi.org/10.1080/00364827.1996.10413624

Pethybridge, H.R., Choy, C.A., Polovina, J.J., Fulton, E.A., 2018. Improving Marine Ecosystem Models with Biochemical Tracers. Annu. Rev. Mar. Sci. 10, 199-228. https://doi.org/10.1146/annurev-marine-121916-063256

Pinnegar, J.K., Campbell, N., Polunin, N.V.C., 2001. REGULAR PAPERS Unusual stable isotope fractionation patterns observed for fish host-parasite trophic relationships. J. Fish Biol. 59, 494-503. https://doi.org/10.1111/j.1095-8649.2001.tb02355.x

$\mathrm{R}$ Core Team, 2018. R: A language and environment for statistical computing. $\mathrm{R}$ Foundation for Statistical Computing, Vienna, Austria. URL https://www.R-project.org/.

Rault, J., Le Bris, H., Robert, M., Pawlowski, L., Denamiel, M., Kopp, D., 2017. Diets and trophic niches of the main commercial fish species from the Celtic Sea. J. Fish Biol. 91, 1449-1474. https://doi.org/10.1111/jfb.13470

Reiner, J.L., Kannan, K., 2011. Polycyclic Musks in Water, Sediment, and Fishes from the Upper Hudson River, New York, USA. Water. Air. Soil Pollut. 214, 335-342. https://doi.org/10.1007/s11270-010-0427-8

Ren, Z., Liu, J., Huang, W., Cao, L., Cui, W., Dou, S., 2019. Antioxidant defenses and immune responses of flounder Paralichthys olivaceus larvae under methylmercury exposure. Comp. $\begin{array}{lllll}\text { Biochem. Physiol. Part C Toxicol. Pharmacol. 225, } 108589 . & \end{array}$ https://doi.org/10.1016/j.cbpc.2019.108589

Rodríguez Martín-Doimeadios, R.C., Tessier, E., Amouroux, D., Guyoneaud, R., Duran, R., Caumette, P., Donard, O.F.X., 2004. Mercury methylation/demethylation and volatilization pathways in estuarine sediment slurries using species-specific enriched stable isotopes. Mar. Chem., 
Special Issue in honor of Dr. William F. Fitzgerald 90, 107-123. https://doi.org/10.1016/j.marchem.2004.02.022

Rooney, N., McCann, K.S., 2012. Integrating food web diversity, structure and stability. Trends Ecol. Evol. 27, 40-46. https://doi.org/10.1016/j.tree.2011.09.001

Sagerup, K., Savinov, V., Savinova, T., Kuklin, V., Muir, D.C.G., Gabrielsen, G.W., 2009. Persistent organic pollutants, heavy metals and parasites in the glaucous gull (Larus hyperboreus) on Spitsbergen. Environ. Pollut. 157, 2282-2290. https://doi.org/10.1016/j.envpol.2009.03.031

Sanders, D., Thébault, E., Kehoe, R., Veen, F.J.F. van, 2018. Trophic redundancy reduces vulnerability to extinction cascades. Proc. Natl. Acad. Sci. 115, 2419-2424. https://doi.org/10.1073/pnas.1716825115

Smith, J.W., Wootten, R., 1978. Anisakis and Anisakiasis, in: Lumsden, W.H.R., Muller, R., Baker, J.R. (Eds.), Advances in Parasitology. Academic Press, pp. 93-163. https://doi.org/10.1016/S0065-308X(08)60573-4

Sures, B., 2006. How parasitism and pollution affect the physiological homeostasis of aquatic hosts. J. Helminthol. 80, 151-157. https://doi.org/10.1079/joh2006346

Sures, B., 2004. Environmental parasitology: relevancy of parasites in monitoring environmental pollution. Trends Parasitol. 20, 170-177. https://doi.org/10.1016/j.pt.2004.01.014

Sures, B., 2001. The use of fish parasites as bioindicators of heavy metals in aquatic ecosystems: a review. Aquat. Ecol. 35, 245-255. https://doi.org/10.1023/A:1011422310314

Sures, B., Knopf, K., 2012. Individual and combined effects of cadmium and 3,3',4,4',5pentachlorobiphenyl (PCB 126) on the humoral immune response in European eel (Anguilla anguilla) experimentally infected with latvea of Anguillicola crassus (Nematoda). [WWW Document]. URL https://www.ncbi.nlm.nih.gov/pubmed/15151150 (accessed 11.20.19).

Sures, B., Nachev, M., Pahl, M., Grabner, D., Selbach, C., 2017. Parasites as drivers of key processes in aquatic ecosystems: Facts and future directions. Exp. Parasitol., Proceedings of the 27th Meeting of the German Society for Parasitology 2016 180, 141-147. https://doi.org/10.1016/j.exppara.2017.03.011

Sures, B., Siddall, R., Taraschewski, H., Sures, B., Siddall, R., Taraschewski, H., 1999. Parasites as Accumulation Indicators of Heavy Metal Pollution. Parasitol. Today 15, 16-21. https://doi.org/10.1016/S0169-4758(98)01358-1

Sures, B., Taraschewski, H., Siddall, R., 1997. Heavy metal concentrations in adult acanthocephalans and cestodes compared to their fish hosts and to established free-living bioindicators. Parassitologia 39, 213-218.

Sweeting, C.J., Polunin, N.V.C., Jennings, S., 2006. Effects of chemical lipid extraction and arithmetic lipid correction on stable isotope ratios of fish tissues. Rapid Commun. Mass Spectrom. 20, 595-601. https://doi.org/10.1002/rcm.2347

Ternes, T.A., Joss, A., Siegrist, H., 2004. Peer Reviewed: Scrutinizing Pharmaceuticals and Personal Care Products in Wastewater Treatment. Environ. Sci. Technol. 38, 392A-399A. https://doi.org/10.1021/es040639t

Thieltges, D.W., Goedknegt, M.A., O’Dwyer, K., Senior, A.M., Kamiya, T., 2019. Parasites and stable isotopes: a comparative analysis of isotopic discrimination in parasitic trophic interactions. Oikos 128, 1329-1339. https://doi.org/10.1111/oik.06086

Thompson, R.M., Brose, U., Dunne, J.A., Hall, R.O., Hladyz, S., Kitching, R.L., Martinez, N.D., Rantala, H., Romanuk, T.N., Stouffer, D.B., Tylianakis, J.M., 2012. Food webs: reconciling the structure and function of biodiversity. Trends Ecol. Evol. 27, 689-697. https://doi.org/10.1016/j.tree.2012.08.005

Velasco, F., Olaso, I., 2000. Hake food consumption in the southern Bay of Biscay estimated from a gastric evacuation model. ICES. https://doi.org/ICES CM2000/Q:11.

Webb, M.A.H., Feist, G.W., Fitzpatrick, M.S., Foster, E.P., Schreck, C.B., Plumlee, M., Wong, C., Gundersen, D.T., 2006. Mercury Concentrations in Gonad, Liver, and Muscle of White Sturgeon Acipenser transmontanus in the Lower Columbia River. Arch. Environ. Contam. Toxicol. 50, 443-451. https://doi.org/10.1007/s00244-004-0159-0 
Zhang, X., Xu, Q., Man, S., Zeng, X., Yu, Y., Pang, Y., Sheng, G., Fu, J., 2013. Tissue concentrations, bioaccumulation, and biomagnification of synthetic musks in freshwater fish from Taihu Lake, China. Environ. Sci. Pollut. Res. Int. 20, 311-322. https://doi.org/10.1007/s11356-0121095-6

\section{Supplementary material}

Analytical performances of the method used including limits of quantification (LOQ), recoveries (\%) and precisions.

\begin{tabular}{|c|c|c|c|c|c|}
\hline & & \multicolumn{2}{|c|}{ Merluccius merluccius } & \multicolumn{2}{|c|}{ Anisakis sp. } \\
\hline & LOQ & $\begin{array}{c}\text { Recovery } \\
\text { values }(\%)\end{array}$ & Precision $(\%)$ & $\begin{array}{c}\text { Recovery } \\
\text { values }(\%)\end{array}$ & Precision $(\%)$ \\
\hline \multicolumn{6}{|c|}{ PCB congeners $\left(\mathrm{ng} \mathrm{g}^{-1} \mathrm{dw}\right)$} \\
\hline PCB 18 & 0.1 & 46.2 & 0.2 & 70.7 & 13.0 \\
\hline PCB 28 & 0.2 & 68.3 & 13.1 & 82.7 & 10.6 \\
\hline PCB 31 & 0.2 & 68.3 & 13.1 & 82.7 & 10.6 \\
\hline PCB 44 & 0.1 & 57.5 & 15.2 & 81.5 & 7.8 \\
\hline PCB 52 & 0.1 & 65.9 & 20.0 & 84.1 & 8.1 \\
\hline PCB 101 & 0.1 & 62.8 & 21.8 & 84.1 & 4.4 \\
\hline PCB 118 & 0.1 & 69.3 & 17.1 & 84.7 & 2.9 \\
\hline PCB 138 & 0.2 & 51.7 & 6.2 & 68.8 & 21.6 \\
\hline PCB 149 & 0.1 & 59.1 & 16.5 & 79.8 & 6.1 \\
\hline PCB 153 & 0.2 & 59.6 & 5.3 & 77.1 & 24.4 \\
\hline PCB 180 & 0.3 & 53.9 & 7.6 & 79.6 & 8.9 \\
\hline PCB 194 & 0.5 & 61.4 & 11.3 & 67.4 & 17.6 \\
\hline \multicolumn{6}{|c|}{ Musk fragrances (ng g $\mathrm{g}^{-1} \mathrm{dw}$ ) } \\
\hline ADBI & 0.1 & 102.1 & 2.9 & 87.4 & 3.3 \\
\hline AHMI & 0.1 & 98.2 & 2.6 & 83.2 & 20.4 \\
\hline AHTN & 0.1 & 110.0 & 12.8 & 105.9 & 32.2 \\
\hline ATII & 0.1 & 108.8 & 11.5 & 102.1 & 15.1 \\
\hline HHCB & 0.1 & 111.6 & 14.7 & 100.8 & 7.5 \\
\hline MA & 0.9 & 102.9 & 4.0 & 75.0 & 8.9 \\
\hline
\end{tabular}


Journal Pre-proof

\begin{tabular}{|l|c|c|c|c|c|}
\hline MK & 0.2 & 104.0 & 5.5 & 92.1 & 9.1 \\
\hline MM & 0.1 & 110.1 & 13.0 & 91.7 & 1.8 \\
\hline MX & 0.1 & 108.0 & 10.5 & 94.1 & 12.1 \\
\hline UV-filters (ng g $\left.\mathbf{~}^{-1} \mathbf{d w}\right)$ & & & & & \\
\hline 3-BC & 1.4 & 127.0 & 30.1 & 108.4 & 11.2 \\
\hline EHMC & 0.2 & 111.7 & 14.8 & 123.8 & 11.3 \\
\hline 4-MBC & 0.7 & 108.3 & 10.8 & 102.1 & 20.6 \\
\hline OC & 1.9 & 104.0 & 5.4 & 93.2 & 1.2 \\
\hline OD-PABA & 0.1 & 112.8 & 16.0 & 67.0 & 29.3 \\
\hline
\end{tabular}


Highlights:

- Partial trophic interaction between L3 Anisakis sp. larvae and its host, hake.

- $\quad P C B$ transfer may result from the uptake of lipids from hake by the parasites.

- Highly MeHg level in hake can weaken immune system and increase Anisakis sp. number. 


\section{Declaration of interests}

$\bigotimes$ The authors declare that they have no known competing financial interests or personal relationships that could have appeared to influence the work reported in this paper.

$\square$ The authors declare the following financial interests/personal relationships which may be considered as potential competing interests: 